\title{
Arthropods at the Interface between Monoculture and Native Forest
}

\section{Leandro Finger ${ }^{1^{*}}$}

https://orcid.org/0000-0003-4512-3429

\section{Poliana Quitaiski ${ }^{1}$}

https://orcid.org/0000-0002-1509-7226

\section{Denise Lange ${ }^{2}$}

https://orcid.org/0000-0002-5386-7252

\section{Carla Daniela Câmara ${ }^{1}$}

https://orcid.org/0000-0001-9381-2558

${ }^{1}$ Federal Technological University of Paraná, Post-Graduate Program in Environmental Technologies, Medianeira, Paraná, Brazil; ${ }^{2}$ Federal Technological University of Paraná, Santa Helena, Paraná, Brazil.

Editor-in-Chief: Paulo Vitor Farago

Associate Editor: Camila Fediuk de Castro Guedes

Received: 2019.12.10; Accepted: 2021.09.02.

*Correspondence: fingerleandro@hotmail.com; Tel.: +55-45-93300-3134 (L.F.).

\section{HIGHLIGHTS}

- Species richness in monoculture decreases as the distance from natural areas increases.

- Natural areas can act as refuge for pollinators, parasitoids, and predators.

- Natural areas can act as source of ecosystem services for monocultures.

- Natural areas can contribute economically for agriculture by providing pollination.

\begin{abstract}
The current study has investigated whether arthropod richness in soybean monoculture (Glycine max) decreases, whereas the abundance, mainly of herbivores, increases as distance from Parque Nacional do Iguaçu (PNI) increases. Active and passive arthropod collections were performed at different distances $(5,50,300$ and $600 \mathrm{~m})$ from PNI. Arthropod richness in agricultural area decreased as distance from PNI increased. Results have shown that Conservation Units can act as source of ecosystem services for surrounding monocultures. The presence of pollinators in collections has confirmed the important role played by protected natural areas in agriculture, since they contribute to this economic activity by providing ecosystem services such as pollination.
\end{abstract}

Keywords: Agricultural Pests; Commodities; Protected Areas; Parque Nacional do Iguaçu; Pollinator. 


\section{INTRODUCTION}

Arthropods are the largest animal phylum [1,2] capable of significantly contributing to several ecosystem services such as pollination, soil formation, population control, organic matter decomposition and nutrient cycling [3-5]. Habitat fragmentation leads to biodiversity loss and hinders connectivity between ecological populations and communities. The idea of protecting areas of great ecological importance, such as Conservation Units, arise as tool to protect biodiversity, as well as to ensure ecological integrity and genetic diversity within populations $[6,7]$. Conservation of natural environments within or near rural properties is of paramount importance to help providing ecosystem services and improving agricultural yield [8,9], since they act as refuge and source of food for pollinators, parasitoids, and predators that, in their turn, are hampered by intense and constant management in traditional agriculture. Parque Nacional do Iguaçu (PNI) is a Conservation Unit located in Southern Brazil. It covers 185,262.5 hectares of the Brazilian territory and is the largest Atlantic Forest remnant in South America [10]. PNI is surrounded by extensive areas of intensive agricultural use, which may be favored by ecosystem services performed by different organisms deriving from PNI. Therefore, the aim of the current study was to assess the important role played by PNI as source of ecosystem services for the monoculture surrounding it, based on arthropods' richness in this monoculture at different distances from PNI. The here in tested hypothesis was that arthropods' richness in the investigated agricultural area decreased as the distance from PNI increased.

\section{MATERIAL AND METHODS}

The study was carried out from December 2016 to January 2017 in a private property $\left(25^{\circ} 26^{\prime} 16.47^{\prime \prime S}\right.$ and $53^{\circ} 57^{\prime} 43.18^{\prime \prime}$ W) in Serranópolis do Iguaçu Country $\left(25^{\circ} 24^{\prime} 51^{\prime \prime}\right.$ S and 54 $02^{\prime} 19^{\prime \prime}$ W), Paraná State, Brazil (Figure 1). The property has approximately 240 hectares and was selected to be investigated because it borders PNI and is far from any other forest fragments that could influence results in the current study. According to the Köppen classification, the climate in the region is of the subtropical type: rainfall rates range from $1,600 \mathrm{~mm}$ to $1,900 \mathrm{~mm}$ and mean temperature reaches $22^{\circ} \mathrm{C}$ in the warmest months and less than $18^{\circ} \mathrm{C}$ in the coldest ones [11].
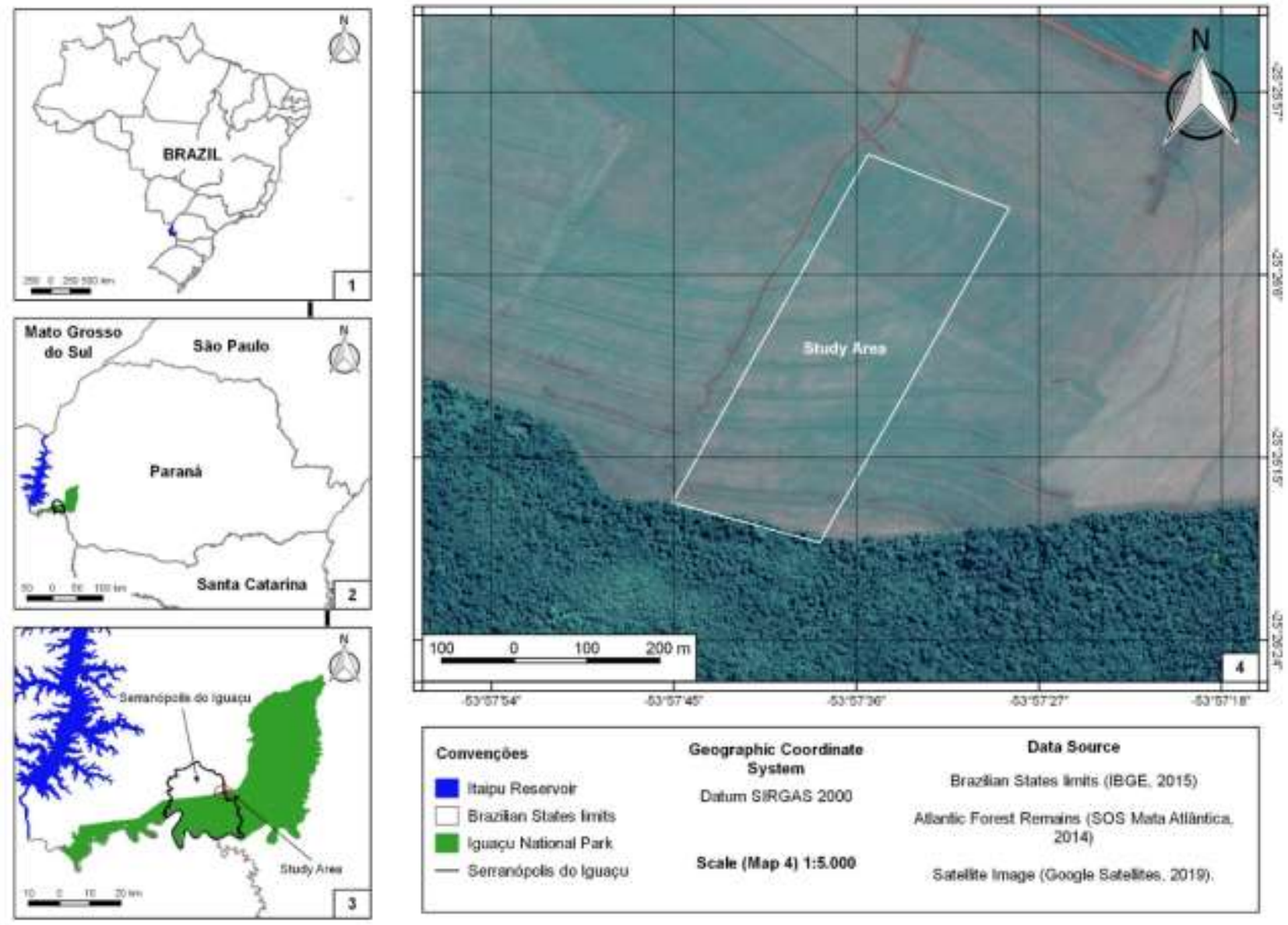

Figure 1. Map of Serranópolis do Iguaçu Country, Paraná State Brazil. Parque Nacional do Iguaçu is highlighted in green in the Country map and the study site location is emphasized in it. 
Soybean was planted in the study site on September 22, 2016, based on the no-till mode, i.e., without previous soil plowing or tilling. NIDERA (NA 5909 RG) was the variety planted in the study site; this variety is grown in Western Paraná State and reaches its flowering stage at 43 to 53 days after emergence. Flowering remains for up to 28 days and maturation takes place at 115 to 130 days after emergence [12].

Four $200 \mathrm{~m}$ long transects within the soybean crop, parallel to PNI, were defined for arthropod collection purposes. The first transect was installed $5 \mathrm{~m}$ from PNI; the second one was installed $50 \mathrm{~m}$ from it; the third one was located $300 \mathrm{~m}$ from PNI; and the fourth one was placed $600 \mathrm{~m}$ from it. Active and passive arthropod collections were performed. Active collection was carried out with the aid of entomological net (puçá - with "voil" cloth), on sunny days without excessive wind. Scans were performed in all transects, for two days (in January 2017, when plants were blooming), from 7:00 am to 6:00 pm. In total, 24 samples were collected in each transect at 1-hour interval between samplings. Each sampling covered a 20 meters linear walk along the transects; the net was held at the upper third of plants. Collection site was changed at every hour, by advancing $20 \mathrm{~m}$ farther into the transects. Collected arthropods were placed in labeled containers and stored in freezer $\left(-15^{\circ} \mathrm{C}\right)$ for subsequent identification.

Passive collection was performed with the aid of two flight interception traps $(1.20 \mathrm{~m}$ tall and $2.05 \mathrm{~m}$ wide) fixed on iron rods and equipped with $1.5 \mathrm{~mm} \times 3.0 \mathrm{~mm}$ mesh. They were installed in January 2017, 1 $\mathrm{m}$ above the ground, $2 \mathrm{~m}$ far from the PNI border, and 20 meters apart from each other. Both traps remained exposed for three days, from 7:00 am to 6:00 pm, on sunny days, under conditions similar to those of the active collection. Entomological glue was evenly applied throughout the net to enable arthropods' fixation. Thus, all arthropods flying from the PNI into the plantation, and vice versa, adhered to the net as soon as they collided with it. Captured arthropods were pulled away with forceps, stored in properly labeled containers filled with $70 \%$ alcohol and taken to the UTFPR Biological Sciences laboratory, Medianeira Campus, for subsequent identification.

All collected arthropods were identified at family level based on group-specific taxonomic keys and on information provided by experts in this field. The literature used to classify families based on prevalent food habits comprised studies conducted by [13-23]. All collected adult individuals were subjected to morphological specification.

Species accumulation curve was plotted for each transect, based on active collection data to enable checking sample sufficiency. Chao 2 index was used to estimate transects' richness because the number of rare species was larger than $25 \%$, as well as because this index uses not only uniques, but also dupliques [24]. The association among distance from PIN, individuals' abundance and morphospecies richness was evaluated and graphically depicted. One-way ANOVA and Tukey post-hoc tests, both at 5\% significance level, were used to investigate differences in arthropod abundance and in morphospecies richness among all four analyzed transects. It was done based on data of 24 active collection samples. Graphs were plotted and analyses were performed in GraphPad Prism software, version 5.0.

\section{RESULTS}

In total, 1,983 arthropods distributed in 10 orders, 59 families and 104 morphospecies were collected (Table 1). Species accumulation curves have reached asymptote in four evaluated transects, a fact that evidenced sample sufficiency (Figure 2). However, the estimate index has shown that the number of species could be larger. The current study did not find morphospecies belonging to order Araneae due to massive incidence of immature individuals. 
Table 1. Total abundance of individuals / richness of arthropod morphospecies collected at the Forest/Soybean crop interface with the aid of traps (passive collection), and at soybean crop with the aid of entomological net (active collection), in four transects located at different distances from Parque Nacional do Iguaçu, Serranópolis do Iguaçu Country, PR, Brazil, in 2017, January.

\begin{tabular}{|c|c|c|c|c|c|c|c|c|c|}
\hline \multirow[b]{2}{*}{ Class } & \multirow[b]{2}{*}{ Order } & \multirow[b]{2}{*}{ Family } & \multirow{2}{*}{$\begin{array}{l}\text { Passive } \\
\text { collection }\end{array}$} & \multicolumn{4}{|c|}{ Active Collection on Transects } & \multirow[b]{2}{*}{ Total } & \multirow[b]{2}{*}{ Food Habit* } \\
\hline & & & & $5 \mathrm{~m}$ & $50 \mathrm{~m}$ & $300 \mathrm{~m}$ & $600 \mathrm{~m}$ & & \\
\hline \multirow{54}{*}{ 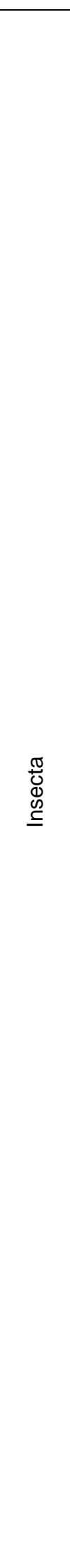 } & \multirow{16}{*}{ Coleoptera } & Anobiidae & $0 / 0$ & $0 / 0$ & $1 / 1$ & $0 / 0$ & $0 / 0$ & $1 / 1$ & Herb. \\
\hline & & Cantharidae & $16 / 3$ & $1 / 1$ & $6 / 3$ & $0 / 0$ & $0 / 0$ & $23 / 4$ & Pred. \\
\hline & & Carabidae & $0 / 0$ & $1 / 1$ & $2 / 1$ & $0 / 0$ & $0 / 0$ & $3 / 1$ & Pred. \\
\hline & & Cerambycidae & $2 / 2$ & $1 / 1$ & $0 / 0$ & $0 / 0$ & $0 / 0$ & $3 / 3$ & Herb. \\
\hline & & Chrysomelidae & $18 / 5$ & $63 / 3$ & $192 / 4$ & $442 / 3$ & $433 / 3$ & $1148 / 5$ & Herb. \\
\hline & & Cicindelidae & $0 / 0$ & $1 / 1$ & $0 / 0$ & $1 / 1$ & $9 / 1$ & $11 / 1$ & Pred. \\
\hline & & Coccinelidae & $5 / 4$ & $3 / 2$ & $4 / 2$ & $1 / 1$ & $0 / 0$ & $13 / 5$ & Pred. \\
\hline & & Curculionidae & $1 / 1$ & $0 / 0$ & $0 / 0$ & $0 / 0$ & $0 / 0$ & $1 / 1$ & Herb. \\
\hline & & Elateridae & $2 / 1$ & $0 / 0$ & $0 / 0$ & $0 / 0$ & $0 / 0$ & $2 / 1$ & Herb. \\
\hline & & Lycidae & $0 / 0$ & $0 / 0$ & $1 / 1$ & $0 / 0$ & $0 / 0$ & $1 / 1$ & Herb. \\
\hline & & Melyridae & $0 / 0$ & $3 / 1$ & $6 / 1$ & $12 / 1$ & $17 / 1$ & $38 / 1$ & Pred. \\
\hline & & Passalidae & $0 / 0$ & $1 / 1$ & $0 / 0$ & $2 / 1$ & $0 / 0$ & $3 / 1$ & Herb. \\
\hline & & Scarabaeidae & $3 / 2$ & $0 / 0$ & $0 / 0$ & $0 / 0$ & $0 / 0$ & $3 / 2$ & Herb./Sap. \\
\hline & & Scolytidae & $1 / 1$ & $0 / 0$ & $0 / 0$ & $0 / 0$ & $0 / 0$ & $1 / 1$ & Herb. \\
\hline & & Silphidae & $4 / 1$ & $10 / 1$ & $10 / 1$ & $11 / 1$ & $5 / 1$ & $40 / 1$ & Herb./Nec. \\
\hline & & Tenebrionidae & $3 / 1$ & $0 / 0$ & $1 / 1$ & $1 / 1$ & $0 / 0$ & $5 / 1$ & Sap. \\
\hline & Dermaptera & Spongiphoridae & $3 / 1$ & $0 / 0$ & $0 / 0$ & $0 / 0$ & $0 / 0$ & $3 / 1$ & Pred. \\
\hline & \multirow{10}{*}{ Diptera } & Agromyzidae & $0 / 0$ & $1 / 1$ & $0 / 0$ & $0 / 0$ & $0 / 0$ & $1 / 1$ & Herb. \\
\hline & & Asilidae & $0 / 0$ & $1 / 1$ & $0 / 0$ & $0 / 0$ & $0 / 0$ & $1 / 1$ & Pred. \\
\hline & & Lonchaeidae & $3 / 1$ & $0 / 0$ & $1 / 1$ & $0 / 0$ & $0 / 0$ & $4 / 1$ & Herb. \\
\hline & & Otitidae & $1 / 1$ & $0 / 0$ & $0 / 0$ & $0 / 0$ & $0 / 0$ & $1 / 1$ & Herb. \\
\hline & & Sarcophagidae & $12 / 1$ & $6 / 1$ & $2 / 1$ & $0 / 0$ & $1 / 1$ & $21 / 1$ & Nec. \\
\hline & & Sciaridae & $8 / 1$ & $10 / 1$ & $22 / 1$ & $8 / 1$ & $1 / 1$ & $49 / 1$ & Herb./Sap. \\
\hline & & Syrphidae & $15 / 6$ & $10 / 4$ & $5 / 3$ & $2 / 2$ & $1 / 1$ & $33 / 6$ & Pred. \\
\hline & & Tabanidae & $0 / 0$ & $1 / 1$ & $0 / 0$ & $0 / 0$ & $0 / 0$ & $1 / 1$ & Pred. \\
\hline & & Tachinidae & $24 / 4$ & $13 / 4$ & $10 / 3$ & $5 / 3$ & $0 / 0$ & $52 / 4$ & Paras. \\
\hline & & Tephritidae & $0 / 0$ & $2 / 1$ & $2 / 1$ & $0 / 0$ & $0 / 0$ & $4 / 1$ & Herb. \\
\hline & \multirow{10}{*}{ Hemiptera } & Cicadellidae & $16 / 6$ & $10 / 5$ & $3 / 2$ & $1 / 1$ & $0 / 0$ & $30 / 8$ & Herb. \\
\hline & & Alydidae & $0 / 0$ & $1 / 1$ & $0 / 0$ & $1 / 1$ & $0 / 0$ & $2 / 2$ & Herb. \\
\hline & & Cercopidae & $3 / 1$ & $1 / 1$ & $0 / 0$ & $0 / 0$ & $0 / 0$ & $4 / 1$ & Herb. \\
\hline & & Dictyopharidae & $4 / 1$ & $3 / 1$ & $1 / 1$ & $1 / 1$ & $0 / 0$ & $9 / 1$ & Herb. \\
\hline & & Lygaeidae & $3 / 1$ & $10 / 1$ & $3 / 1$ & $0 / 0$ & $1 / 1$ & $17 / 1$ & Herb. \\
\hline & & Membracidae & $1 / 1$ & $0 / 0$ & $1 / 1$ & $0 / 0$ & $0 / 0$ & $2 / 1$ & Herb. \\
\hline & & Miridae & $2 / 2$ & $2 / 2$ & $1 / 1$ & $1 / 1$ & $0 / 0$ & $6 / 2$ & Herb. \\
\hline & & Pentatomidae & $1 / 1$ & $3 / 2$ & $0 / 0$ & $4 / 2$ & $1 / 1$ & $9 / 2$ & Pred./Herb. \\
\hline & & Reduviidae & $4 / 2$ & $3 / 2$ & $4 / 3$ & $9 / 2$ & $13 / 3$ & $33 / 6$ & Pred. \\
\hline & & Tingidae & $0 / 0$ & $1 / 1$ & $3 / 1$ & $0 / 0$ & $0 / 0$ & $4 / 1$ & Herb. \\
\hline & \multirow{9}{*}{$\begin{array}{c}\text { Hymenopter } \\
\text { a }\end{array}$} & Pompilidae & $1 / 1$ & $0 / 0$ & $0 / 0$ & $0 / 0$ & $0 / 0$ & $1 / 1$ & Pred. \\
\hline & & Anthophoridae & $0 / 0$ & $0 / 0$ & $1 / 1$ & $0 / 0$ & $2 / 1$ & $3 / 1$ & Herb. \\
\hline & & Apidae & $25 / 2$ & $24 / 3$ & $20 / 3$ & $11 / 1$ & $9 / 4$ & $89 / 5$ & Herb. \\
\hline & & Colletidae & $2 / 1$ & $0 / 0$ & $1 / 1$ & $0 / 0$ & $1 / 1$ & $4 / 1$ & Herb. \\
\hline & & Evaniidae & $0 / 0$ & $0 / 0$ & $1 / 1$ & $0 / 0$ & $0 / 0$ & $1 / 1$ & Paras. \\
\hline & & Halictidae & $4 / 3$ & $10 / 3$ & $2 / 2$ & $3 / 1$ & $1 / 1$ & $20 / 3$ & Herb. \\
\hline & & Ichneumonidae & $3 / 2$ & $0 / 0$ & $5 / 1$ & $4 / 1$ & $0 / 0$ & $12 / 2$ & Paras. \\
\hline & & Sphecidae & $1 / 1$ & $1 / 1$ & $0 / 0$ & $0 / 0$ & $0 / 0$ & $2 / 1$ & Pred. \\
\hline & & Vespidae & $5 / 3$ & $1 / 1$ & $0 / 0$ & $0 / 0$ & $0 / 0$ & $6 / 3$ & Pred. \\
\hline & \multirow{4}{*}{ Lepidoptera } & Noctuidae & $22 / 1$ & $0 / 0$ & $0 / 0$ & $0 / 0$ & $0 / 0$ & $22 / 1$ & Herb. \\
\hline & & Arctiidae & $10 / 1$ & $0 / 0$ & $1 / 1$ & $1 / 1$ & $0 / 0$ & $12 / 1$ & Herb. \\
\hline & & Nymphalidae & $11 / 3$ & $13 / 3$ & $3 / 1$ & $1 / 1$ & $1 / 1$ & $29 / 4$ & Herb. \\
\hline & & Pyralidae & $15 / 1$ & $1 / 1$ & $2 / 1$ & $2 / 1$ & $1 / 1$ & $21 / 1$ & Herb. \\
\hline & \multirow{2}{*}{ Orthoptera } & Romaleidae & $1 / 1$ & $29 / 3$ & $22 / 2$ & $298 / 2$ & $45 / 2$ & $126 / 3$ & Herb. \\
\hline & & Tettigoniidae & $0 / 0$ & $10 / 1$ & $0 / 0$ & 2/1 & $0 / 0$ & $12 / 1$ & Herb. \\
\hline & Odonata & Libellulidae & $1 / 1$ & $0 / 0$ & $0 / 0$ & $0 / 0$ & $0 / 0$ & $0 / 0$ & Pred. \\
\hline & Neuroptera & Chrysopidae & $1 / 1$ & $1 / 1$ & $0 / 0$ & $0 / 0$ & $0 / 0$ & $2 / 1$ & Pred. \\
\hline
\end{tabular}


Cont.

\begin{tabular}{|c|c|c|c|c|c|c|c|c|c|}
\hline \multirow{2}{*}{ Class } & \multirow{2}{*}{ Order } & \multirow{2}{*}{ Family } & \multirow{2}{*}{$\begin{array}{l}\text { Passive } \\
\text { collection }\end{array}$} & \multicolumn{4}{|c|}{ Active Collection on Transects } & \multirow{2}{*}{ Total } & \multirow{2}{*}{ Food Habit ${ }^{\star}$} \\
\hline & & & & $5 \mathrm{~m}$ & $50 \mathrm{~m}$ & $300 \mathrm{~m}$ & $600 \mathrm{~m}$ & & \\
\hline \multirow{4}{*}{ 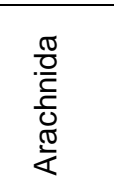 } & \multirow{4}{*}{ Araneae } & Salticidae & 3 & 3 & 0 & 1 & 0 & 7 & Pred. \\
\hline & & Thomisidae & 2 & 5 & 5 & 2 & 3 & 17 & Pred. \\
\hline & & Oxyopidae & 0 & 2 & 0 & 1 & 0 & 3 & Pred. \\
\hline & & Araneidae & 1 & 4 & 5 & 0 & 5 & 15 & Pred. \\
\hline Total & & & $262 / 72$ & $266 / 63$ & $348 / 50$ & $559 / 35$ & $548 / 26$ & $1.983 / 103$ & - \\
\hline
\end{tabular}

* Pred.: Predators; Herb.: Herbivores and/or pollen feeders; Paras.: Parasitoids; Onív.: Omnivores; Nec.: Necrophagous; Sap.: Saprophagous. The literature used to classify families based on prevalent food habits comprised studies conducted by [13-23].

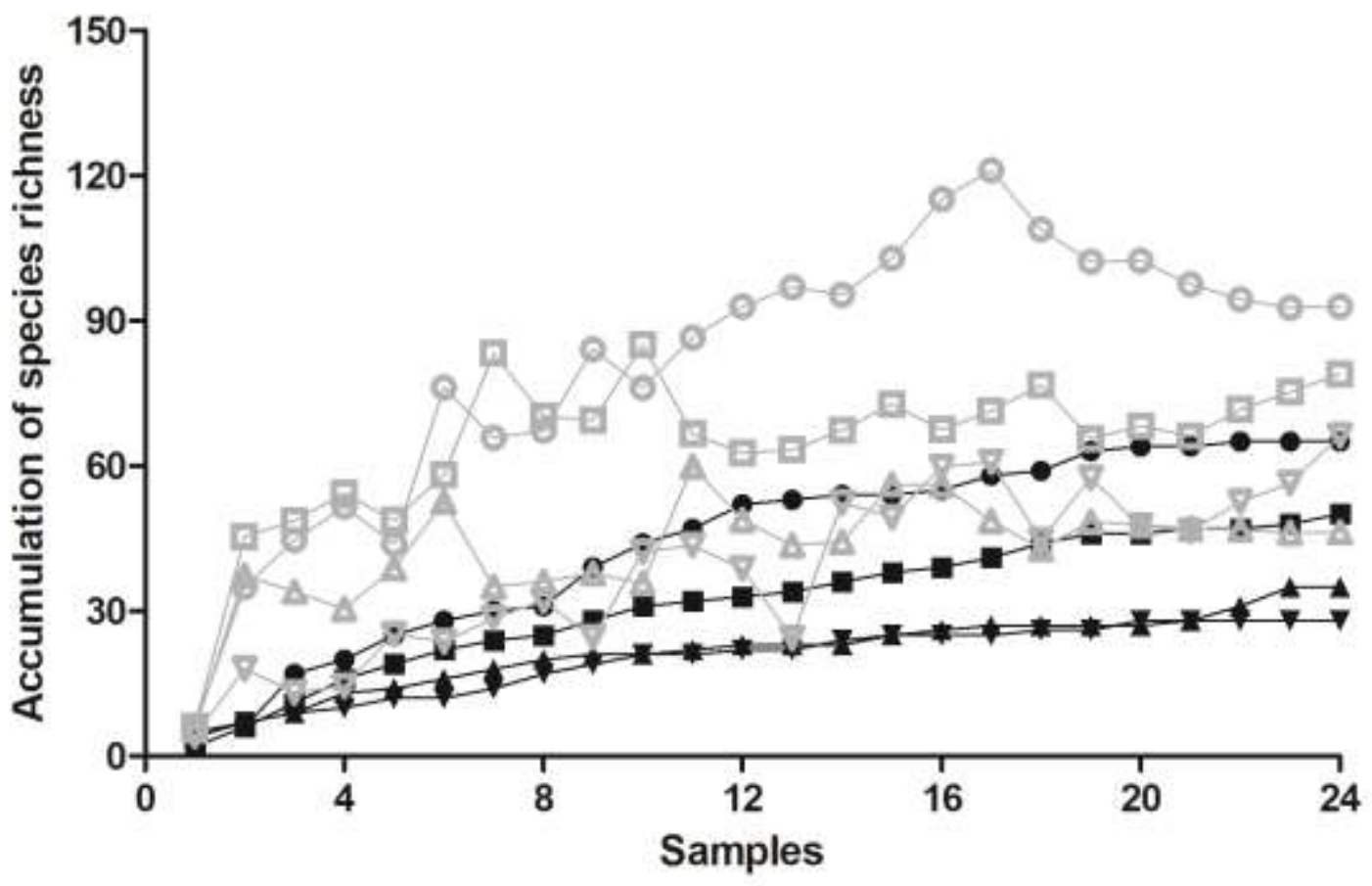

Observed:

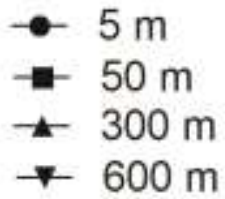

Estimated:

$5 \mathrm{~m}$

$50 \mathrm{~m}$

$300 \mathrm{~m}$

$600 \mathrm{~m}$

Figure 2. Observed and estimated (Chao 2 index) arthropod morphospecies' accumulation curves generated for transects established in soybean crops at different distances $(5,50,300$ and $600 \mathrm{~m})$ from Parque Nacional do Iguaçu. Collections were carried out in Serranópolis do Iguaçu Country, PR in 2017, January.

Collected arthropods were mostly herbivores (87.7\%); they were followed by predators ( $8.46 \%)$ and other groups (3.84\%) (Table 1, Figures $3 a$ and $3 b$ ). Coleoptera was the most representative order in morphospecies richness and individuals' abundance; it was followed by Hymenoptera and Diptera. Odonata was the least abundant order. Maecolaspis calcarifera Bechyné, 1954 (Coleoptera: Chrysomelidae), which is a relevant soy pest, stood out for the abundance of collected individuals (63 individuals in the $5 \mathrm{~m}$ transect; 192, in the $50 \mathrm{~m}$ transect; 442, in the $300 \mathrm{~m}$ transect; and 433, in the $600 \mathrm{~m}$ transect, 1,130 individuals, in total). Order Hymenoptera, presented prevalence of Apis mellifera Linnaeus, 1758 (Apidae) (74 individuals). 

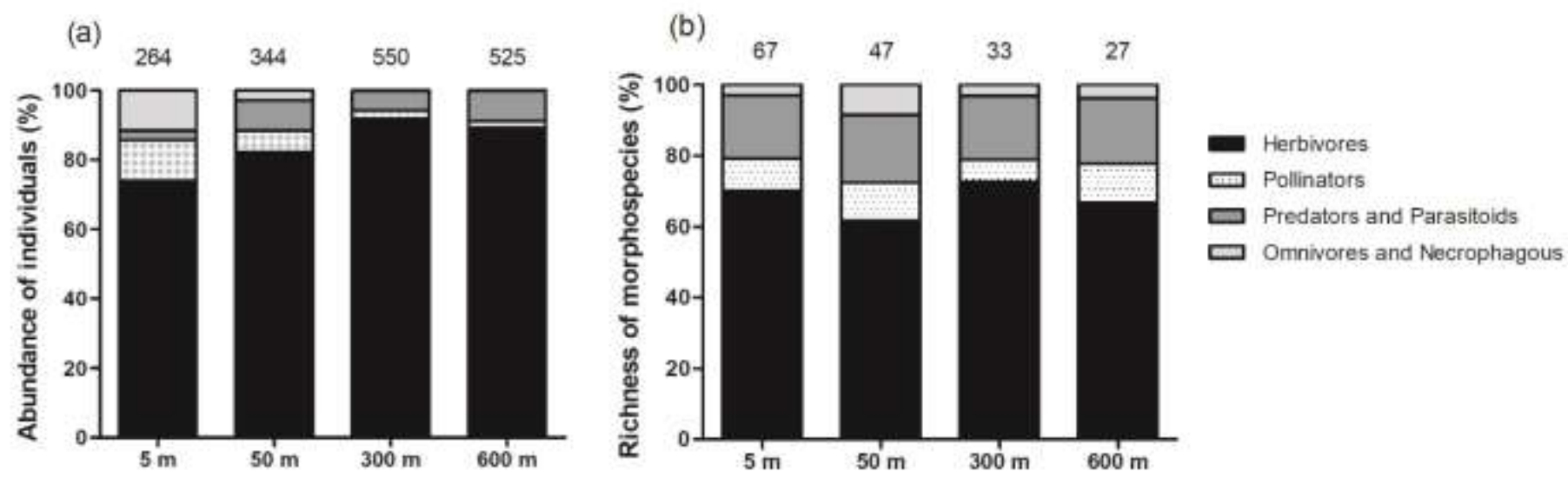

Figure 3. Arthropod (a) individuals' abundance and (b) morphospecies richness rates found in soybean crop in all four transects located at different distances from Parque Nacional do Iguaçu. The total value recorded for each transect is presented above each bar. Collections were carried out For Review Only Serranópolis do Iguaçu Country, PR, in January 2017. Individuals belonging to order Araneae were not taken into consideration in graph (b).

Likely soybean pollinators were identified among morphospecies Exomalopsis sp. (Spinola, 1853), Augochloropsis sp. (Cockerell, 1897), Ceratina sp. (Latreille, 1802) and Oxaea sp. Klug, 1807, in addition to A. mellifera and Tetragonisca angustula Latreille, 1811. Families Reduviidae, Chrysopidae, Melyridae and Coccinelidae, stood out among predators. They were more abundant in the $300 \mathrm{~m}, 5 \mathrm{~m}, 300 \mathrm{~m}$ and $50 \mathrm{~m}$ transects respectively. Cicindelidae individuals were mainly collected in the $600 \mathrm{~m}$ transect. Cantharidae and Syrphidae were mostly found in the $5 \mathrm{~m}$ and $50 \mathrm{~m}$ transects.

Both individuals' abundance and morphospecies richness recorded different values among the evaluated transects $(F=12.02 ; p<0.001$; Figure $4 a$ and $F=5.474 ; p<0.05$; Figure $4 b$, respectively). The closest transect to PNI (5 m distance) was the one recording the lowest individuals' abundance and the highest morphospecies richness. The farther transect from PNI $(600 \mathrm{~m})$ recorded the lowest species richness. The $300 \mathrm{~m}$ transect recorded the greatest abundance of organisms. These results have evidenced inverse relationship between morphospecies richness and individuals' abundance, negative relationship between morphospecies richness and distance from PNI, as well as positive relationship between arthropod abundance and distance from PNI.

(a)

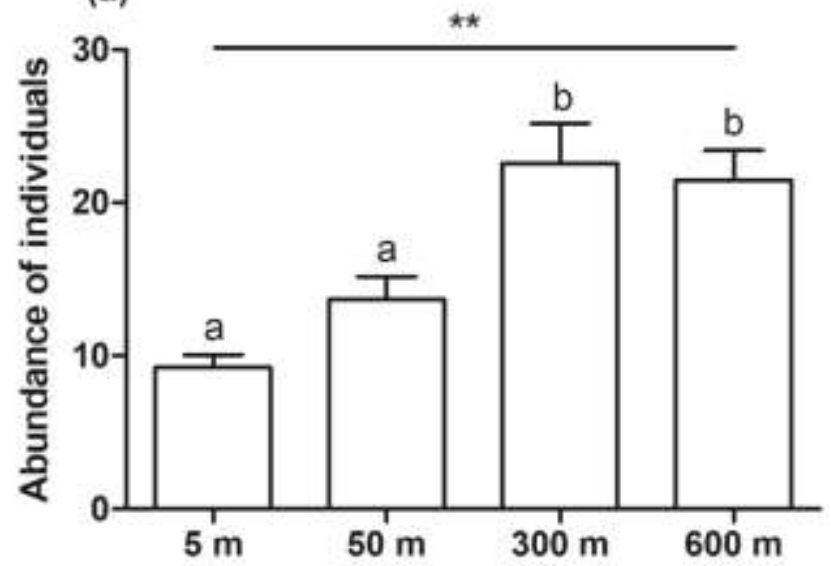

(b)

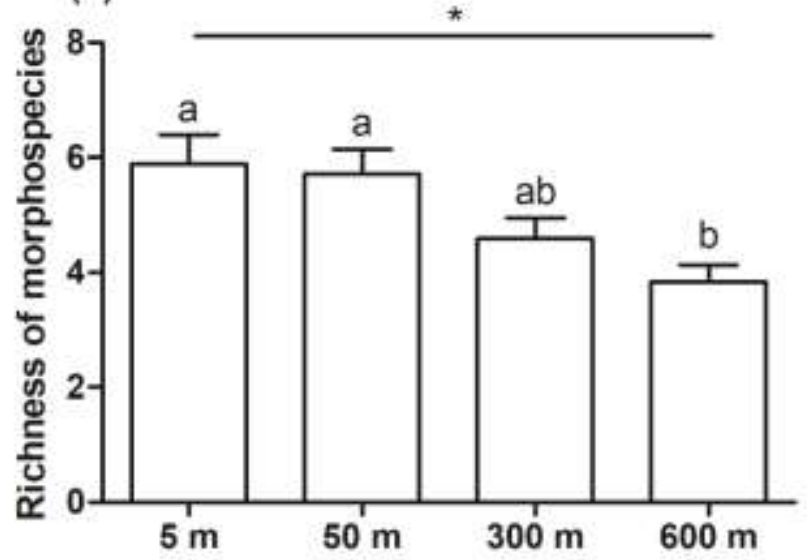

Figure 4. Mean and standard deviation of (a) individuals' abundance and (b) morphospecies richness rates found in soybean crop in all four transects located at different distances from Parque Nacional do Iguaçu. Collections were carried out in Serranópolis do Iguaçu, PR, in January 2017. Asterisks and letters represent statistical difference $(p<0.05)$ among different transects, based on ANOVA and Tukey post-hoc test, respectively.

\section{DISCUSSION}

The initial hypothesis about morphospecies richness in the current study was corroborated. The farther we moved into the soybean monoculture and away from the PNI, the lower the arthropod richness. However, 
the same outcome was not observed for individuals' abundance, which increased as the distance from PNI also increased.

There is consensus in the literature that natural habitats tend to present higher species richness due to availability of different food resources and nesting sites, whereas monoculture areas tend to host more simplified communities, i.e., poor in species richness [25-28]. Accordingly, in this study, the closest transects to PNI presented higher richness due to park's influence, since it acts as source of species diversity (i.e., arthropods) for the monoculture. The influence of the investigated protected area as source of species decreased as the distance from PNI increased.

The distance threshold of PNI's influence as source species associated fragment over lesser complex fragments (in this case, monoculture) changed according to species' dispersal capacity and food availability $[29,30]$. Some species, such as the ones belonging to orders Diptera and Hymenoptera, have excellent flying skills and can fly for kilometers at once [31-33]. Other species, such as most Hemiptera, have a more limited dispersion ability and can reach few dozen meters [14]. Coleoptera insects were classified as bad at flying $[14,34,35]$, although the species most often found in the current study, $M$. calcarifera, was observed in all transects. This result may have been influenced by this species' large population size in this area, which generates strong interspecific competition pressure, besides the fact that the transect closest to PNI presented greater predator richness. Yadav and coauthors [36] have evaluate predators in rice culture during crop and found Cicindelidae specimens close to natural areas. Bortolotto and coauthors [37] observed greater Syrphidae abundance close to the edge of forest fragments, mainly low pest infestation periods in wheat crops; this outcome suggest that these areas act as resource providers. These very same authors believe that, predators move away from the edge of forest fragments as pest infestation increases.

According to Schmidt and coauthors [29], individuals' dispersion results from several factors such as predation risk and competition (intra or interspecific) for resources. These factors may have increased the abundance of some species in transects farther from PNI, since few species could reach them and it, reduce interspecific competition and predation risk.

Other studies focused on evaluating the agricultural areas/forest fragments interface have also shown decreased arthropod species richness and increased individuals' abundance as the distance from the edge of forest fragments increased. These studies were carried out in Canada [38], Argentina [39], France [40], South Africa [41] and Colombia [42]. Thus, it is essential maintaining and promoting natural vegetation strips in highly mechanized monoculture areas to increase biodiversity and enable important ecosystem services without having to sacrifice production areas [42]. However, the cited authors pointed out that small fragmented areas are not enough to maintain biodiversity in these places or to guarantee ecosystem services, since they require larger areas connected to each. There are extensive Permanent Preservation Areas connecting forest fragments to PNI in Western Paraná State. However, several forest fragments are isolated, mainly the ones located in private areas surrounded by monocultures [43]. This scenario makes populations inhabiting forest fragments increasingly vulnerable to extinction, since it decreases genetic variability and increases inbreeding rates. This phenomenon would lead to forest fragments increasingly poor in speciesrichness, which would act much lesser as source of ecosystem services [4].

However, larger areas such as Conservation Units can maintain arthropod biodiversity. Consequently, they can maintain environmentally and economically valuable ecosystem services such as pollination. Figure 3 depicts pollinators observed in all transects. Nevertheless, in percentage terms, the abundance of this group was higher in the closest areas to PNI and it decreased as the distance from the protected area increased. Although soybean plants are capable of performing self-pollination, some experiments have suggested that pollination can increase crop yield [44,45]. This finding highlight, once again, the important role played by forest remnants in agriculture.

However, maintaining large native forest remnants is a hard task to be accomplished, when direct economic benefits are necessary to encourage the agricultural sector [46]. Thus, studies about the economic value of ecosystem services can help farmers to better understand the important role played by these services and by native forest remnants in agriculture. It is essential conducting further research to provide information about the effectiveness of conservation areas in maintaining biodiversity [47].

\section{CONCLUSION}

Based on the current results, it was possible concluding that arthropod richness in the investigated agricultural area decreased as the distance from PNI increased. The presence of pollinators has confirmed the important role played by protected natural areas in agriculture, since they contribute to this economic activity by providing ecosystem services such as pollination. 
Funding: This research was funded by Coordenação de Aperfeiçoamento de Pessoal de Nível Superior (CAPES), through scholarship for the first author.

Acknowledgments: We would like to thank Cristhiane Rohde for helping in the identification of arthopod families and to Fernando Cesar Vieira Zanella for the identification of bee species.

Conflicts of Interest: The authors declare no conflict of interest.

\section{REFERENCES}

1. Hamilton AJ, Basset Y, Benke KK, Grimbacher PS, Miller SE, Novotný V, et al. Quantifying uncertainty in estimation of tropical arthropod species richness. Am Nat. 2010;176(1):90-5.

2. Stork NE, Mcbroom J, Gely C, Hamilton AJ. New approaches narrow global species estimates for beetles, insects, and terrestrial arthropods. Proc Natl Acad Sci U S A. 2015;112(24):7519-23.

3. Altieri MA. The ecological role of biodiversity in agroecosystems. In: Paoletti MG, editor. Invertebrate Biodiversity as Bioindicators of Sustainable Landscapes. Kobo; 1999. p. 19-31.

4. Swift MJ, Izac AM, Van Noordwijk, M. Biodiversity and ecosystem services in agricultural landscapes - are we asking the right questions? Agric Ecosyst Environ. 2004;104(1):113-34.

5. Bianchi FJ, Booij CJH, Tscharntke T. Sustainable pest regulation in agricultural landscapes: a review on landscape composition, biodiversity and natural pest control. P Roy Soc B-Biol Sci.2006; 273(1595): 1715-27.

6. Cafaro P, Primack R. Ecological Integrity: Evaluating Success in National Parks and Protected Areas. In: Wiley J, editor. ELS; 2012.

7. Rossetti MR, Tscharntke T, Aguilar R, Batáry P, Novotny V. Responses of insect herbivores and herbivory to habitat fragmentation: a hierarchical meta-analysis. Ecol Lett. 2017; 20(2): 264-72.

8. Tscharntke T, Klein AM, Kruess A, Steffan-Dewenter I, Thies C. Landscape perspectives on agricultural intensification and biodiversity-ecosystem service management. Ecol Lett. 2005; 8(8): 857-74.

9. Zhang W, Ricketts TH, Kremen C, Carney K, Swinton SM. Ecosystem services and dis-services to agriculture. Ecol Econ. 2007;64(2):253-60.

10. de Souza RF, do Amaral MS, Galvão F, F Filho. Fitossociologia da vegetação arbórea do Parque Nacional do Iguaçu. Ciência Florestal 2017;27(3):853-69.

11. Nitsche PR, Caramori PH, Ricce WS, Pinto LFD. Cartas climáticas do Paraná. Londrina: IAPAR, 2000. Cartas climáticas do Estado do Paraná. Não paginado. Portuguese. [cited 2017 Sep 10]. Available from: //www.iapar.br/pagina-677.html.

12. NIDERA. Catálogo de produtos SUL. Cultivares de soja. Safra 2014-2015. 2014. Portuguese.

13. Fujihara RT, Forti LC, Almeida MC, Baldin ELL, editors. Insetos de Importância Econômica: Guia llustrado para Identificação de Famílias. Botucatu: Fundação de Estudos e pesquisas agrícolas e florestais. UNESP; 2011. Portuguese.

14. Rafael JA, Melo GAR, Carvalho CJB, Casari S, Constantino R, editors. Insetos do Brasil: Diversidade e Taxonomia. Ribeirão Preto: HolosEditora; 2012. Portuguese.

15. Gallo D, Nakano O, Wiendel FM, Silveira Neto S, Carvalho RPL, Batista GC, et al. Entomologia Agrícola. Piracicaba: FEALQ. 2002. Portuguese.

16. Brennan EB, Gill RJ, Hrusa GF, Weinbaum SA. First record of Glycaspis brimblecombei (Moore) (Homoptera: Psyllidae) in North America: Initial observations and predator associations of a potentially serious new pest of eucalyptus in California. Pan-Pac Entomol. 1999;75(1):55-7.

17. SILVA AC, editor. Guia para o reconhecimento de inimigos naturais de pragas agrícolas. Brasília: EMBRAPA. 2013. Portuguese.

18. Dahlsten DL, Rowney DL. The red gum lerp psyllid, a new pest of Eucalyptus species in California. Oakland: University of California; 2000.

19. Prescott KK, Andow DA. Lady beetle (Coleoptera: Coccinellidae) communities in soybean and maize. Environ Entomol. 2016;45(1):74-82.

20. Waichert C, Rodriguez J, Von Dohlen C, Pitts J. Spider wasps (Hymenoptera: Pompilidae) of the Dominican Republic. Zootaxa. 2012: 3353(3353): 1-47.

21. Fuller BW. Predation by Calleidadecora (F.) (Coleoptera: Carabidae) on velvet bean caterpillar (Lepidoptera: Noctuidae) in soybean. J Econ Entomol. 1988;81(1):127-9

22. Bechinski EJ, Pedigo LP. Ecology of predaceous arthropods in lowa soybean agroecosystems. Environ Entomol. 1981;10(5):771-8.

23. Hsin CY, Sellers LG, Dahm PA. Seasonal activity of carabids and the toxicity of carbofuran and terbofos to Pterostichuschalcites. Environ Entomol. 1979;8(1):154-9.

24. Magurran AE. Medindo a diversidade ecológica. Tradução Dana Moiana Vianna. Curitiba: UFPR; 2011. Portuguese. 
25. Almeida S, Louzada J, Sperber C, Barlow J. Subtle land-use change and tropical biodiversity: dung beetle communities in Cerrado grasslands and exotic pastures. Biotropica. 2011;43(6):704-10.

26. Ekroos J, Heliola J, Kuussaari M. Homogenization of lepidopteran communities in intensively cultivated agricultural landscapes. J Appl Ecol. 2010;47(2):459-67.

27. Knops JMH, Tilman D, Haddad N, Naeem S, Mitchell CE, Haarstad J, et al. Effects of plant species richness on invasion dynamics, disease outbreaks, insect abundances and diversity. Ecol Lett. 1999;2(5):286-93.

28. Medan D, Torretta JP, Hodara K, La Fuente EB, Montaldo NH. Effects of agriculture expansion and intensification on the vertebrate and invertebrate diversity in the Pampas of Argentina. Biodivers Conserv. 2011;20(13):3077-100.

29. Schmidt JM, Whitehouse TS, Green K, Krehenwinkel H, Schmidt-Jeffris RA, Sial AA. Local and landscape-scale heterogeneity shape spotted wing drosophila (Drosophila suzukii) activity and natural enemy abundance: Implications for trophic interactions. Agr Ecosyst Environ. 2019;272(1):86-94.

30. Freitas JL, Freitas JL, Pires EPP, Oliveira TTC, Santos NL, Souza MM. Vespas sociais (Hymenoptera: Vespidae) em lavouras de Coffea arabica L. (Rubiaceae) no Sul de Minas Gerais. Rev. Agrogeo Ambiental. 2015;7(3):69-79. Portuguese.

31. Correia FCS, Peruquetti RC, Silva AR, Gomes FA. Distância de voo para forrageamento da abelha uruçu beiço (Meliponaeburnea Friese, 1900). ArqCiênc Vet Zool UNIPAR. 2017;20(3):143-6.

32. Santos GMM, Cruz JD, Marques OM, Gobbi N. Diversidade de vespas sociais (Hymenoptera: Vespidae) emáreas de cerradona Bahia. NeotropEntomol. 2009;38(3):317-20.

33. Prezoto F, Gobbi N. Flight range extension in Polistes simillimus Zikán, 1951 (Hymenoptera, Vespidae). Braz Arch Biol Technol. 2005;48(6):947-50.

34. Polatto LP, Dutra JCS, Alves Junior VV. Biologia reprodutiva de Pyrostegia venusta (Ker-Gawl) Miers (Bignoniaceae) e comportamento de forrageamento dos visitantes florais predominantes. Rev Biol Neotrop. 2007;4(1):46-57. Portuguese.

35. Durães R, Martins WP, Vaz-de-Mellos FZ. Dung beetle (Coleoptera: Scarabaeidae) assemblages across a natural forest-cerrado ecotone in Minas Gerais, Brazil. NeotropEntomol. 2005; 34(5): p. 721-731. Portuguese.

36. Yadav M, Prasad R, Kumari P, Madhu M, Kumari A, Pandey C, Saurabh A, et al. Potential and Prospects of Natural Enemies in Rice Ecosystem in Jharkhand. Int. J. Curr. Microbiol. App. Sci. 2018;7:3389-96.

37. Bortolotto OC, Menezes Júnior AO, Hoshino AT, Campos TA. Distance from the edge of forest fragments influence the abundance of Aphidophagous hoverflies (Diptera: Syrphidae) in wheat fields. Acta Sci Agron. 2016;38(2):15764.

38. Mitchel MGE, Bennett EM, Gonzalez A. Agricultural landscape structure affects arthropod diversity and arthropodderived ecosystem services. AgrEcosyst Environ. 2014;192(1):144-51.

39. González E, Salvo A, Defagó MT, Valladares G. A Moveable Feast: Insects Moving at the Forest-Crop Interface Are Affected by Crop Phenology and the Amount of Forest in the Landscape. Plos One. 2016;5 11(7):1-19.

40. Geslin B, Le Féon V, Folschweiller M, Flacher F, Carmignac D, Motard E, et al. The proportion of impervious surfaces at the landscape scale structures wild bee assemblages in a densely populated region. EcolEvol. 2016;6(18):6599-615.

41. Pryke JS, Samways MJ. Ecological networks act as extensions of protected areas for arthropod biodiversity conservation. J Appl Ecol. 2012;49(3):591-600.

42. Rivera-Pedroza LF, Escobarb F, Philpottc SM, Armbrechta I. The role of natural vegetation strips in sugarcane monocultures: Ant and bird functional diversity responses. Agric Ecosyst Environ. 2019;284:1-10.

43. Seganfredo D, Cunha B, Magalhães VL, Cielo-Filho R, Câmara, CD Landscape Ecology in a Watershed of the Ocoy River, Western Parana State, Brazil. Floresta e Ambiente. 2019;(26)1.

44. Chiari WC, et al. Pollinations of soybean (Glycine max L. Merril) by honeybees (Apis mellifera). Braz Arch Biol Technol. 2005;48(1):31-6.

45. Moreti ACCC, et al. Observações sobre a polinização entomófila da cultura da soja (Glycine max L. Merril). Boletim da Indústria Animal,1998;55:91-4.

46. Tilman D. Global environmental impacts of agricultural expansion: the need for sustainable and efficient practices. Proc Natl Acad Sci U S A. 1999;96(11):5995-6000.

47. Fabricius $C$, Burger M, Hockey PAR. Comparing biodiversity between protected areas and adjacent rangeland in xeric succulent thicket, South Africa: arthropods and reptiles. J Appl Ecol. 2003;40(2):392-403.

2021 by the authors. Submitted for possible open access publication under the terms and conditions of the Creative Commons Attribution (CC BY NC) license (https://creativecommons.org/licenses/by-nc/4.0/). 